\title{
The Law As The Instrument of Right Protection on The Body Integrity of Woman As The Victim of Not Fulfilled Promise to Marry
}

\author{
Lusiana M. Tijow ${ }^{1}$, Fence Wantu ${ }^{2}$ \\ \{lusianamtijow@gmail.com ${ }^{1}$, fence_wantu@gmail.com ${ }^{2}$ \}
}

Law Faculty, State University of Gorontalo ${ }^{1,2}$

\begin{abstract}
The women as the victim of not fulfilled promise to marry refers to problem of injustice law that "may result in" and result in" the women suffered various forms of violence; physical, psychic, sexual, social and economy. The effect result in long- and short-term that may destroy the women dignity finally giving influence to their selfconcept and eliminate possibility of the women to get their essential rights that protected by the constitution. The problem formula in this study referred to how the law and human right becomesprotection instrument of body integrity on women as the victim of not fulfilled promise to marry. This normative law study used method of qualitative judicial analysis. The right of body integrity of women brought them on their body originality and completeness. In this case, the principle of human being as a woman referred to the unity of thought, feeling and bodily that would build the self-concept of a woman and her existence. It became living value of the integrative prestige and dignity of woman describing herself into good developing physical and mental condition, and achieving welfare well. Thus, the woman as the victim of not fulfilled promise to marry has right to get guarantee of law protection from anything that threat her body integrity.
\end{abstract}

Keywords: Law and Human Right, the Right of Body Integrity, The Woman as the Victim of Marriage Promise.

\section{Introduction}

A human has will to do well to others based on a relation between personal with principle of rationality and moral. The law purpose ${ }^{1}$ referred to provide safety, happiness and system in the society. Human and society has responsibility to create side-by-side living and arrange it in justice that the law seen as proper duty for human being. Injustice law is not a law. The reason is because ${ }^{2}$ any state governments always defend their actions by showing real justice inside; 2) Improper law toward the justice principle often considered old fashion and no more used, 3) By conducting injustice, the government actually has conducted outside its authority, thus it is illegal. It showed that the government has right and responsibility to keep the legal certainty.

The nature of law is as the facility for formulation of a justice social rule. It related to all people including women who have will to create a rule that is justice therefore the main

${ }^{1}$ Wirjono Prodjodikoro, Perbuatan Melanggar HukumdipandangdariSudutHukumPerdata, Bandung, Sumur Bandung, , 1976, hlm. 43

${ }^{2}$ Zainuddin Ali, FilsafatHukum, Jakarta, SinarGrafika, 2006, Hlm. 86 
purpose of justice becoming the main focus of formulating the law appropriate to the justice principle. Thus, the law has its authority. Women become legal subject, a social political power that must give substantial contribution in resolving state problem as well as gender problem.

The legal purposes are classified in to 3 (three) streams, namely ${ }^{3}$ :

1. Ethic stream that consider of the basic of legal purpose on achieving justice;

2. Utility stream consider of the basic of legal purpose on create the benefit;

3. Judicial-formal stream consider of the basic of legal purpose on creating legal certainty.

The legal purpose universally such as the opinion of Gustav Radbruch ${ }^{4}$ : 1) Justice, 2) legal certainty in system of social living, 3) Beneficial. However, its implementation often results in stress. Often, the legal certainty and justice has a crush, crush of legal certainty and beneficial, and between justice and the legal certainty. In order to solve this stress, Gustav Radbruch based on his theory used scale of priority that should be applied, where the first priority is always justice, then beneficial and finally the legal certainty. ${ }^{5}$

The body integrity of woman refers to self-concept of personal unity of woman in order to develop her. When there is human, there will be human right and it must be kept highly for anyone without exception. The human right does not depend on other confession; either not depends on confession of society or country. Thus, the country, everywhere, anytime, has responsibility to accept and uphold the human right as the fundamental or basic rights.Oppression and ignorance toward the human right consider against the justice and humanity.

The case of woman as the victim of not fulfilled promise to marry ${ }^{6}$ began with relationship between adult man and woman with no marriage tie only as a couple of lovers. In this relationship, they promise each other to get marry. Mostly, the man says the promise. The promise is said directly, via communication tools or HP suchas WhatsApp, WeChat, Line, and Kakao Talk, SMS (Short Message Service), via computer or others. With this promise, the woman voluntarily gives away her body that the do sexual conduct. However, in the end, the man broke his promise. It shows a cause resulting in an event where for the woman who asking for the promise to marry from the man, whether in condition pregnant or not, the woman often experience various kinds of violence as the victim that finally it affected her body integrity.

The man's deed to the woman as the victim of not fulfilled promise to marry considers against the humanity principle of a woman and this deed refers to action that result in loss and suffering (physical, psychic, sexual, social and economy) to the woman, whether she is pregnant or not. ${ }^{7}$ Moreover, the suffering experienced by the woman in the time or after the violence happened, in fact, proved to be more traumatic than for the man. ${ }^{8}$ However, seriously,

\footnotetext{
${ }^{3}$ Achmad Ali, Mengembara di Belantara Hukum, Cetakan Pertama, Ujung Pandang, Lembaga penerbitan Universitas Hasanudin, 1990, Hlm. 95

${ }^{4}$ http://sharingaboutlawina.blogspot.co.id/2014/12/tujuan-hukum-menurut-gustav-radbruch.html,diunduh pada tanggal02/06/2016, 5.26 AM 
it refers to form of attack or ignorance toward human right that result in losing body integrity of the woman.

Injustice experienced by woman mostly result from hegemony and domination as well as unbalance structure of relation power between man and woman roles. The role of man is constructed to dominate the role of woman. This is the gap of gender relation. In this case, the structure of thinking, social, politic, culture and economy form pattern of relation between individual of society and groups among the society.

The underestimating perspective in the following process result in attitude of egoism and give priority on the dominance than being dominated, or privilege, then authorize, oppression and of course violence of sociopolitical and economy. There are placed up high, considered and given priority, in other hand, there are placed lower, forgotten, and marginalized.

Like what happen to the woman as the victim of not fulfilled promise to marry with strong myth made in our social structure that relationship between man and woman before marriage and they conduct sexual though with the promise to marry, the woman should not believe the promise and she should not give her body. Even, the relationship happens because of love each other.

The fact above is far from the reality seen from the women's experiences. The influence is often disappearing in the process of resolution and court that it make difficulty in resolution (also prevention) of the case of promise to marry. Therefore, it places woman suffering from violence showing phenomenon of Ice Mountain where what is identified and reported often cannot give justice for the woman.

There are many reasons basically that all of them start from how the woman as the victim of not fulfilled promise to marry cannot get legal protection:

1. The woman as the victim of marriage promise is not considered as victim because she considered bad for giving away her body and dignity.

2. When the woman is not pregnant, she can make another relationship, however, when she is pregnant, it becomes the woman's problem.

3. The woman might be left because she is not married yet, it is only broke a promise.

4. The deed is considered as taboo and shameful of herself, it is better to keep silent than getting reaction of being blamed.

5. It is not crime against the country; it is only matter of individual/personal. Thus, there is worry that the legal upholder will not take any real action to find and tae into court the actor and victim that the woman as the victim becomes more stressful.

6. Insensitive legal process and legal upholder with the situation and condition of the woman and moreover how to take care the proof and finding the witnesses.

7. Considering this case containing stigma, reporting the case sometime will result in uncomforted feeling of oneself because the woman feel shame when everyone knows her problem and the consequence she will be left and there is no man who want to marry her.

The perspective and framework above are often bias and corner the woman as the victim of not fulfilled promise to marry and make the legal process getting more difficult and surely he woman will experience unconformity and injustice. The framework to be able to empathy by understanding the experience of the woman as the victim of not fulfilled promise to marry is try to place yourself in the woman characteristic as a victim that we easily find out how far the situation and condition experienced by the woman, how far cause-effect of the situation and condition experienced by the woman as the victim of not fulfilled promise to marry that finally we can make sure the justice for the woman. 
According to the Criminal Code, this case does not belong to crime in the following circumstance $^{9}$ :

1. Two people who have not married yet do sex, although:

a. The conduct considered against or bothers the feeling of social moral.

b. The woman willing to do sex because of trick or promise being married, however the promise broke.

c. The woman become pregnant but the man refuse to marry her or there is any obstacle to marry according to the law.

2. A married man has cause a girl pregnant (meaning he has conducted adultery), however his wife does not make any claim.

3. Someone lives together with his couple without marriage, whereas the conduct considered as a sin and against or bothers the feeling of social value/moral.

The woman as the victim of not fulfilled promise to marry faces difficulty of paradigm as the basic on how the legal scholar and advocate give definition to the law. This condition happens in Indonesia where in general the legal scholars focus only on the definition of law as the norm and basic rules. It isolates the law from the social reality. Thus, the legal product, legal apparatus, and legal culture have not yet appreciated the woman. Then, it implies for woman that she should be able to get her right protected by the constitution, as the form of upholding the woman right in the frame of human right.

The attention toward the criminal victim is purposed that the victim will not be more suffered after experiencing crime, hopefully the victim get protection and guarantee of right fulfillment in front of the law. The limitation of criminal victim covers 3 (three) elements: (1) who is the victim of the crime? (2) What suffer or losses got by the victim? (3) Who responsible and/or how the suffers and losses might be recovered?

Arief Amrullah states that the future criminal law should implement equal protection of criminal law between social protection, the doer and the victim (the potential victim or direct victim) that become ideal concept in order to develop wiser criminal law byconsidering variousinterests above. Therefore, the definition concept of individual protection must be broadening to the protection of actual victim. ${ }^{10}$

The woman as the victim of not fulfilled promise to marry still has constitutional right protected by the law. This right happens because of the nature of human being. The people have it because they get human right directly from the God as their nature (secundum suam naturam). Oppression and ignorance toward Human Right against the justice and humanity, because the basic principle of justice and humanity refer to that all the people have equal dignity with the same rights and duties.

Each human must respect, accept and keep the Human Right with no exception. The body integrity of woman becomes integral part of humanity nature for a woman where her body integrity implants in the nature of human. It results from human aspects as human being. Each person is precious creature of the God the Only One. As stated in the Act 1 number 1 of the Law number 39 of 1999 on The Human Right, the human right refers to a set of right implanted on the nature of human existence as the God and the Only One's creature and refers to bless of the God that must be honored, kept high, and protected by the country, law, government and anyone for the honor and protection of human dignity and prestige. Thus,

${ }^{9}$ Ibid

${ }^{10}$ Arief Amrullah, Perlindungan Hukum Pidana Terhadap Korban Kejahatan Korporasi, (Jember : Universitas Jember, 2008), hlm.13 
when the woman as the victim of not fulfilled promise to marry does not get instrument of legal protection, it means placing the woman into experiencing various forms of violence such as physical, psychic, sexual, social and economy.

\section{Research Purpose}

The purpose of this study refers to analyze how the law and woman right become instrument of protection toward body integrity of the woman as the victim of not fulfilled promise to marry.

\section{Research Method}

The study is normative legal research, where the writers tend to study on legal bases that study to find out the legal bases available in positive law, written and unwritten ones. The written positive law focus on the Law of formulating legislative regulation and related regulation, the principles of formulating the legislative regulation, and the court decisions related to violence toward woman. This study gives priority on philosophical approach, statute approach, conceptual approach and case approach. The legal material being collected is calculated and analyzedbased on legal reasoning that one of them refers to legal interpretation.

\section{Discussion}

\subsection{The Law, Human Right and Woman Right}

Indonesia as a legal country places the guarantee of human right absolutely in the constitution. The constitution as the highest legal source in a country becoming the basic in conducting the country, in which one of its functions is to limit the authority and guaranty the right and freedom of its citizen. A set of legal regulation appearsin order to create peace and comfort condition. How the legal role as stabilizer in the society covers many factors. One of them is source of where the legal comes from. The Universal Declaration of Human Right becomes official interpretation toward the United Nation Decree, containing more detail of some rights listed as the human rights.

The constitutional right of citizen covering the human right and citizen right guaranted by the Fundamental Constitution of 1945 apply for each of Indonesian citizen. ${ }^{11}$ It appears in the formula using phrase "each people", "all citizen", "each of citizen", or "”each citizen", showing that each individual citizen has constitutional right without discrimination, whether based on tribe, religion, political belief, or gender.

Even more, the Fundamental Constitution of 1945 stated that "Anyone has freedom from discriminative treatment based on anything and has right to get protection against the discrimination". Therefore, if there is any regulation or treatment that discriminate certain

\footnotetext{
${ }^{11}$ Jimly Asshiddiqie, Hak Konstitusional Perempuan dan tantangan Penegakannya, Disampaikan pada acara Dialog Publik dan Konsultasi Nasional Komnas Perempuan "Perempuan dan Konstitusi di Era Otonomi Daerah: Tantangan dan Penyikapan Bersama”, Jakarta, 27 Nopember 2007
} 
citizen, it considered against the human right and the constitutional right of the citizen, and of course against the Fundamental Constitution of 1945.

Thus, any woman of Indonesian Citizen has the same constitutional right as the man of Indonesian Citizen. The woman also has right to not be treated discriminatively based on her status as a woman, or other differences. All the constitutional right described previously refers to the constitutional right of any woman as the Indonesian Citizen. This constitutional right related to the state confession of subject of the constitutional right or citizen, in this case, those who accepted legally and legitimated by the law as a citizen of Indonesia. Thus, they have the same right in any matters as the Indonesia citizen.

The Fundamental Constitution of Indonesian Republic 1945 Act 28A verse (1) toAct 28J verse (2) related to human right as well as Act 29 verse (2) stated that related "The country guaranty the freedom of each citizen to choose his religion and to do devotion based on the religion and belief'. This act is the most proper one to fulfill the requirement called as the act of human right resulted from the original draft of the Fundamental Constitution of 1945. While the other regulations, such as Act 27 verses (1) and (2), Act 28, Act 30 verse (1), Act 31 verse (1), and Act 32 verses (1) and (2) are not regulation on guarantee of human right in the actual meaning, but they have relation to the definition of the citizen right.

The human right ${ }^{12}$ is called as the basic right because it considered as the fundamental where all the organizations must develop to live together and refers to the law principles. The meaning of basic right is clear if seen as living humanism that must be organized since the human realize of their place, duty and function in the world. The concept of Human Right revealed as integral basic right given by Allah to the human that need to be honored and protected. The concept of basic right resulted from pancasila admit the rights directly from the God the Only One for the human as the natural right and respect human dignity and prestige as well as human as social and individual creature.

The Law of Indonesian Republic Number 39 of 1999 on the Human Right has arranged in detail of the right to live and right to not being eliminated forcedly and not being killed, the right to have family and continue the heredity, right to develop oneself, right to get justice, right of personal freedom, right od safe feeling, right of welfare, right to participate in the government, woman right, children right, and right of religious freedom. ${ }^{13}$

The Woman Right considered as the right belong to the woman that must get guarantee of the rights basically in the humanity dignity and for the humanity. The appearance of Human Right concept is in order to develop consciousness of human being on the necessity of admitting, respecting, and achieving integrated and complete human being. The woman right refers to human right. It gives statement that the rights embedding on the woman belong to human right, because the woman is human who born with freedom, has dignity, the same as the man, thus, she cannot be discriminated in any fields. ${ }^{14}$

Based on history of Woman Right development as part of human right, it cannot be separated from tough struggle of woman specially the feminism including when Indonesia participated in ratifying it. ${ }^{15}$ The border of Woman Right is as follow:"The Right of Woman and Girl Right are unity part, not marginalized, and inseparable from the universal human right. The full and equal participation of woman in the political, personal, economy, social

\footnotetext{
${ }^{12}$ Ibid ,Hlm 230

${ }^{13}$ PenjelasanatasUndang-Undang RI Nomor 39 Tahun 1999 tentang HAM

${ }^{14}$ Ida Sampit Karo, Karo dalam Tapi Omas Ihromi, et.al. (penyunting), Penghapusan Diskriminasi Terhadap Wanita, (Bandung: Alumni, 2006),hlm.237.

${ }^{15}$ AgusPurwadianto. Op.cit.,hlm. 158
} 
and culture in national, regional and international stages and eliminated any kinds of discrimination based on gender belongs to the main purpose of international society". ${ }^{16}$

Based on the border, the elements of woman right define as the human right show specialty of the purpose and morality interest for the woman as the legal owner of the Woman Right covering full participation, equality and discrimination as result of sexism ${ }^{17}$. Other definition of the Woman Right is formulated as follows: " The rights embedding of a woman that naturally created as human being the same as the man, to be specific it refers to the right to get the same opportunity and responsibility the as for man in any field of living". ${ }^{18}$

CEDAW refers to Bill of Rights for Women comprehensively for the first time in specific admit the Woman Right. As an instrument of the HumanRight international, Cedaw become the first universal arranging the Woman Right. The main fundamental given by CEDAW in the developing of Human Right is markedby appearing of clear definition on discrimination against women and equality. Cedaw arranges scope of Woman Right and the State duty to guaranty the fulfillment of the Woman Right. ${ }^{19}$

CEDAW follows the three principles, first, the principle of substantive equality, this principle accept that the woman is in unequal position and thus the woman must be treated differently in order to get equal benefit and final result. This principle makes sure the equality in opportunity, access and benefit, and result (equality of opportunity, equality of access, and equality of result $)^{20}$. Second, the principle of Non Discrimination,CEDAW states inequality between the man and woman as the result of social construction. Thus, the proactive action must be conducted in order to eliminate it. The Act 1 of CEDAW states: "Discrimination against woman means each differentiation, marginalization or limitation made based on gender, that have influence or purpose to decrease or eliminate acceptant, obtain or usage of human right and principle freedom in the fields of politic, economy, sociocultural, civic, or anything by the woman, regardless their marital status, based on equality between man and woman". ${ }^{21}$ Third, the Principle of State Responsibility, CEDAW decides the state responsibility (Acts 2-5 CEDAW) to prevent, forbid, identify and conduct action, give sanction toward discriminative treatment, provoke woman right and equality between man and woman through proactive action and accelerate the defacto equality. It means the country must guaranty and make sure the Woman Right to be applied in reality, in other word, the country responsibility cover two aspects, namely: (a) Responsibility to provide tool, way, opportunity, effective mechanism to protect the Woman Right. (b) The responsibility to achieve equal and fair result, in the level public and private ${ }^{22}$.

The above rule strictly states the existence of ${ }^{23}$ legal protection to "a whole Indonesian nation and homeland". The meaning of "all" shows on the individuals and covered by keeping

\footnotetext{
${ }^{16}$ The Viena Declaration and Program Action (1983).Batasan ini dikukuhkan lama dalam Deklarasi Beijing 1995 karena sebelumnya tak ada rumusan khusus Hak Asasi Perempuan dalam Deklarasi. Kovenan Hak Sipil dan Politik (berupa" daftar" apa yang tidak boleh di lakukan pemerintah pada rakyatnya) maupun kovenan hak ekonomi, social dan budaya (berupa " daftar" apa yang seharusnya dilakukan pemerintah untuk rakyatnya) PBB. Ibid. ${ }^{17}$ Ibid

${ }^{18}$ Ida SampitKaroKaro, Op.cit. 238

${ }^{19} \mathrm{R}$. Valentina Sagala dan EllinRozana, Op.Cit, Hlm 13

${ }^{20} \mathrm{Ibid}, \mathrm{HIm} .17$

${ }^{21}$ Ibid, Hlm. 18

${ }^{22}$ Ibid

${ }^{23}$ S.F. Marbun, Peradilanadministrasi Negara danUpayaAdminitratif di Indonesia, Liberty, Yogyakarta, Hlm. 349
} 
each individuality, while ${ }^{24 ،}$ a whole" shows that individualityeliminated and all covered as a complete unity including the woman. This rule is achieved through set of legal regulation that must be obeyed and applied. The effort of upholding the woman right must be conducted from the regulation, structural and culture sides. The legal regulations giving specific treatment to the woman with equality and balance perspective is necessary to uphold the woman right.

The law must be able to achieve justice to all Indonesian people including give protection guarantee to the body integrity and honor of the woman as the victim of not fulfilled promise to marry. The right of body integrity of woman becomes the basic right of a woman and central attention in applying comprehensive rights and significant because it makes the humanity side of woman as the focus of the Human Right concern.

The law principally refers to reflection of woman right as part of human right, cannot be eliminated, integral and cannot be separated. The understanding of woman right become part of human right as value, concept and norm living and developing in the society and claim for duty to get protection guaranteeand duty to uphold it. Thus, the law contains justice or not, it depends on the Human Right included and arranged or guaranteed by the law. The law is not seen as reflection of the authority only, but it must give protection to the citizen right. The law based on humanity value and accepts the Human right, the norms must contain precious values that keep high the human dignity and guaranty the Human Right.

\subsection{The Right of Body Integrity}

Most of women do not know their right because in their life rarely talking of it. The function of body integrity belong to each individual or private, not belong to group or public, because who has right to arrange and keep the body is the owner no other people. The woman body is an identity differing it from the man body, its appearance, function, and anatomy configuration. Moreover, the woman body related to constructive matters socially and culturally in the role and function. ${ }^{25}$ In the function, the woman body placed as being hegemony thing by body domination and (or) man passion.

The body integrity ${ }^{26}$ refers to description of ideal body relate to body completeness of someone implanting in the person. The Body Integrity of a woman means a whole or completeness of the woman. The woman will feellosingher body integrity when she loses one of her body components such as feminine ${ }^{27}$ organ (virginity or woman vagina).

The nature of body integrity for the woman as the victim of not fulfilled promise to marry refers to a whole unity and completeness of thought, feeling, and human body with selfacceptance as complete personal as the collaboration of physical, psychological, emotional, aspiration, and achievementcharacteristics that will construct the self-concept of the woman completely to develop.

With the body integrity, woman will more understand her condition suffered and experienced based on her experience. In general, man and woman will always feel loss of the body integrity when losing one of body parts (leg, hand, finger) or specific part of woman that basically will result in feeling of a great losing.It is like what the woman as the victim of not fulfilled promise to marry experience. The great of losing feeling when her body given to the man based on the promise to marry her however the man deny and broke his promise or statement that should be fulfilled.

\footnotetext{
${ }^{24}$ Ibid

${ }^{25}$ Hardiman, dalamLusiana M Tijow, Op Cit, Hlm. 118

${ }^{26}$ Ibid

${ }^{27}$ Ibid
} 
In his book ofViolence and The Sacred, Rene Girard (1993) states that woman body contain two elements contradicting each other, first is the sanctity of womb and nipple. Womb and nipple are symbols of the coming of new people and his life. Secondis menstruation. Therefore, any violence related to the woman body will bring consequence to the doer.

Related to the right of body ${ }^{28}$ integrity, the fourth World Conference of United Nation in the woman work program (FWCW), Beijing, China: 4-15 September 1995, paragraph 112, study deeply of the General Secretary of the United Nation in any forms of violence against the woman in line with the right of body integrity in the United Nation Document A.162/122/Add paragraph 277 states that the Right of body integrity used increasingly to get guarantee needed to protect all the people and specially the woman against violence and harassment resulting in decreasing of health, freedom, and self-integrity from any threats.

Based on the fact above, it shows phenomenon of woman body losing its ideal selfconcept that inside and what someone willing of him/herself, thus, it places woman in not conducive situation toward what being experienced and suffered. The situation experienced by the woman as the victim of not fulfilled promise to marry legitimate various forms of injustice, oppression, and finally violence and ignorance of the woman right.

\subsection{The Woman as The Victim of Not Fulfilled Promise to Marry}

At the beginning, the violence against woman is like conventional crime where it is considered as specific character crime that is specification on the woman victim. However, there is little regulation arranging the victim and its protection. ${ }^{29}$ Whereas, if comprehensive examination applied to this criminal problem, it should not ignorance the role of crime happened.

The material truth must get attention as the purpose to achieve in examination a crime. The role of victim considered to be strategic, that it can decide that the criminal actor get appropriate punishment of his deed. The limitation of criminal victim can be decided in the science of victimology; victimology is a science studying the position and role of victim in a crime. It conducted in the reason that any crime will include the doer and the victim.

The definition of victim, whether found by the expert or from the legitimation regulation covers:

a. A victim is someone experiencing physical, mental suffers, and/or economic losses resulted from a criminal action ${ }^{30}$

b. A victim is who suffering physical and mental as the result of other's action searching fulfillment of someone interest or other people that against the right of suffered party ${ }^{31}$

c. A victim is individual or group of people suffering physical, mental or emotional suffers, emotional, economic or experiencing ignorance, decrease, or opression of his basic right, as the direct result of serious human right violence, including rapping victim. ${ }^{32}$

\footnotetext{
${ }^{28}$ Sexual Declaration Right/Hak-Hak Seksual Deklarasi IPPF Organisasi dunia dari organisasi nasional yang bekerja dengan dan untuk masyarakat dan individu.IPPF adalah pemberi pelayanan global dan memimpin untuk melakukan advokasi Kesehatan seksual, Kesehatan reproduksi, Hak-hak Seksual dan hak reproduksi bagi semua orang.

${ }^{29}$ Made Darma Weda, Beberapa catatan Tentang Korban Kejahatan Korporasi dalam Bunga rampai Viktimisasi, (Bandung: Eresco, 1995),hlm. 200.

${ }^{30}$ Pasal 1 angka 2 PP No. 44 Tahun 2008

${ }^{31}$ AriefGosita Op.cit.,hal 63

${ }^{32}$ Pasal 1 angka 5 UU No,27 Tahun 2004 , tentang Komisi Kebenaran dan Rekonsiliasi
} 
Act 1 verse (2) of the Law number 13 of 2006 on the Protection of Witness and Victim states that " victim is the one who experiences physical and mental violence and/or economic losses as result of a criminal action" thus, shortly, what happened to the woman as the victim of not fulfilled promise to marry resulting in physical, psychic, sexual, and social violence includes as action or attitude conducted by resulting losses for the woman and as the direct effect of ignorance and violence against the human right.

In the Indonesian Dictionary, it defines the term ingkar and janji. The definition of ingkar $^{33}$ are :

a) Not justify, deny, not accept, disavow

b) Not fulfill

c) Disobey, unwilling

The definition of $j a n j i^{34}$ are:

a) Statement that states willingness and capability to do

b) Agreement between two parties (each of them willing and capable to do something)

c) Rule requirement must be fulfilled

Based on the definitions of ingkarandjanjiabove, the writers ${ }^{35}$ get definition of ingkar janji as denial and not fulfilled of statement or agreement that state willingness and capability to do something. Not fulfill promise to marry means broken the promise conducted before legal marriage. As stated above, it refers to denial and not fulfilled statement or agreement that state willingness and capability to do something by the two parties.

Taking a look the condition of legal upholder that not consider to the existence of and low attention to the victim condition result from less understanding on the study of victim including the woman as the victim of not fulfilled promise to marry who experiencing physical, psychic, social and economy violence. Basically, the woman as the victim has right to get protection because it related to uphold the woman right.

The absence of protection toward body integrity of the woman as the victim of not fulfilled promise to marry means automatically eliminate possibility for the woman to get her right as protected by the constitution. It gives implication on the upholding the woman right in the framework of human right. Thus, its legal instrument must give guarantee of legal certainty and reflect justice that the protection toward body integrity of the woman as the victim of not fulfilled promise to marry becomes justice for the woman.

\section{Summary}

The constitution as the highest legal sources in a country becoming base in conducting the country, where one of its functions is to limit authority and guaranty basic right and freedom of its citizen. The law must be able to achieve justice for all Indonesian peopleincluding giving guarantee of protection toward body integrity toward the woman as the victim of not fulfilled promise to marry. The right of woman body integrity becomes basic right of a woman and becomes central concern for the woman in implementing her most comprehensive rights and necessary because making the side of woman humanity, as the focus of Human Right

\footnotetext{
${ }^{33}$ Departemen Pendidikan dan Kebudayaan Republik Indonesia, Kamus Besar Bahasa Indonesia, dalam Lusiana M Tijow Op.Cit, Hlm. 97

${ }^{34}$ Ibid

${ }^{35}$ Ibid
} 
concern. The law basically refers to reflection of woman right as part of human right, cannot be eliminated, integral and inseparable. The understanding of woman right is part of human right as value, concept and norm living and developing in the society and guaranty responsibility to get the protection guarantee as well as duty to keep it. Thus, whether the law contain justice or not, it depend on the Human Right included and arranged or guaranteed by the law. The law is not seen as the authority reflection only, but it must give protection toward the citizen right. The law is based on humanity values and accept the Human Right. The norms containing the honor values keep high the human dignity and guaranty the Human Right.

\section{Bibliography}

[1]. Bazar Harahap dan Nawangsih Sutardi, 2006, Hak Asasi Manusia dan Hukumnya, Jakarta, Perhimpunan cendekiawan Independen Repoblik Indonesia (PECIRINDO)

[2]. Masyur Effendi, Perkembangan Dimensi Hak Asasi Manusia dan Proses Dinamika penyusunan Hak Asasi Manusia, Ghalia Indonesia

[3]. Achie Sudiarti Luhulima, 2014, CEDAW Menegakkan Hak Asasi Perempuan, Jakarta, Yayasan Pustaka Obor Indonesia

[4]. Agnes Widanti, 2005, Hukum Berkeadilan Gemder: Aksi-Interaksi Kelompok Buruh Perempuan Dalam Perubahan Sosial, Jakarta-Kompas

[5]. Bambang Waluyo, 2011, Viktimolgi Perlindungan Korban \& Saksi, Jakarta, Sinar Grafika

[6]. D Kelly Weisberg, 1993, Feminist Legal Theory, Foundations, Temple university Press, Philadelphia

[7]. Horoepoetri, Arimbidan R Valentina, 2004, Percakapan tentang Feminisme vs Neoliberalisme, Institute Perempuan dan debt Watch Indonesia, Bandeng, dilihat juga dalam R Valentina dan Ellin Rozna, 2007, Pergulatan Feminisme \& HAM, HAM untuk perempuan HAM untuk keadilan sosial, Bandung, Institute Perempuan cetakan pertama

[8]. Ida Sampit Karo, Karo dalam Tapi Omas Ihromi, et.al. (penyunting), 2006,Penghapusan Diskriminasi Terhadap Wanita, Bandung, Alumni

[9]. J.E Sahetapy, Modernisasi dan Viktimologi, 1987, Sinar Harapan, Jakarta

[10].Lusiana Margareth Tijow, 2017, Perlindungan Hukum Terhadap Integritas Tubuh Perempuan Korban Tidak Dipenuhinya janji Kawin Dalam Perspektif Hak Asasi Manusia, Malang, Disertasi, Universitas Brawijaya. 